DOI: 10.46340/eujem.2020.6.4.2

\author{
Lidiya Shergina, PhD in Economics \\ ORCID ID : https://orcid.org/0000-0001-9031-0616 \\ Kyiv National Economic University named after Vadym Hetman, Ukraine
}

\author{
Alla Zhemba, PhD in Economics \\ ORCID ID : https://orcid.org/0000-0003-0268-3258 \\ National University of Water and Environmental Engineering, Rivne, Ukraine \\ Vita Kovtun, PhD in Economics \\ ORCID ID : https://orcid.org/0000-0001-7212-6700 \\ Kyiv National Economic University named after Vadym Hetman, Ukraine

\section{FORMATION OF MODERN MODEL OF RESOURCES MANAGEMENT IN THE ERA OF GLOBALIZATION}

\begin{abstract}
The publication considers the features of defining resource management as a qualitatively new model of environmental management in the spatial context. Ways of ensuring rational use and conservation of natural resource potential on the criteria of sustainable development are outlined. It has been proven that environmental degradation is a key factor in economic development; economic growth is an integral part of economic development. Qualitative transformations, which take place in the context of intense economic growth, are a powerful impetus for the transition of the economy from pre-industrial to industrial, from industrial to post-industrial stage of development. Economic development, accompanied by structural changes, contributes to the reduction of man-made load on the environment.

Keywords: environmental management, resource management model, economic mechanism of environmental management, economic growth, structural shifts, environmental development of economic development.
\end{abstract}

Problem setting. The main objective of the state regional policy of Ukraine at the present stage of development is to create conditions that will allow the regions to fully realize their existing potential, make the maximum contribution to the national economy, and gain competitive advantages in the foreign market. Only the prudent policy of the state and its regions in the context of the formation of a modern model of natural resource management can ensure that these tasks are fulfilled. Unfortunately, it can be stated that resource dominance in the context of regional development in the priority state tasks is still absent. These gaps occur in the Millennium Development Goals ${ }^{1,2,3}$, especially in the Ukrainian version.

It is also important to note that a certain disadvantage of existing theories of economic development is the neglect of the environment. Sustaining the environment should become an organic element not only of economic theory but also of the economic development of all countries in the world. It is a healthy environment that is a key factor in economic development for both present and future human civilization. The idea of protecting and preserving the environment is the basis of sustainable development.

The purpose of the paper. To fill a niche of scientific research concerning the development of resource management ideology in the spatial context, to better formulate the strategy of the natural resource management of the region.

\footnotetext{
${ }^{1}$ Стратегія національної екологічної політики на 2010-2020 роки, 2010 (Кабінет Міністрів України). Офіиійний вісник України <http://www.ueplac.kiev.ua/downloads/outputs/output_00331.pdf> (2020, June, 20).

2 Цілі розвитку тисячоліття - Україна (Міністерство економіки України). Національна доповідь.

$<$ http://un.org.ua/images/SDGs_NationalReportUA_Web_1.pdf> (2020, June, 20).

${ }_{3}^{3}$ Розпорядження про затвердження Національного плану дій з охорони навколишнього природного середовища на 2011-2015 роки, 2011 (Кабінет міністрів України). Офіиійний сайт Верховної Ради України $<$ https://zakon.rada.gov.ua/laws/show/577-2011-\%D1\%80> (2020, June, 20).
} 
Presentation of the main material. Formation of theoretical and methodological, organizational and economic foundations of environmental economics and resource management have always been in the focus of scientists, experts and practitioners and duly reflected in scientific works of many domestic and foreign scientists and economists, including A. Balatsky, B. Burkinsky, O. Veklic, T. Galushkina, L. Grinov, M. Dolishny, B. Danylyshyn, S. Doroguntsov, E. Mishenin, L. Melnik, V. Kravtsiv, V. Tregobchuk, Y. Tunytsy, M. Hvesik, V. Shevchuk, E. Khlobistov and others ${ }^{1,2,3,4,5}$.

Scientists have analyzed the features of the relationship between nature, society and economy, which confirms the close relationship between natural and economic factors and the development of society. However, the problem of multi-vector interpretation of some concepts remains unresolved today. In particular, this refers to "resource management" and the many related terms used in the scientific field.

In recent decades, a system of environmental management has been finally established in Ukraine ${ }^{6}$. There are two main periods of development of this system:

- regulatory - from the 1960s to the early 1990s, when a number of legislative acts on environmental protection were adopted;

- ecological and economic, since 1991, when the Law of Ukraine "On Environmental Protection" was introduced, which laid down the principles of formation of economic mechanisms of environmental management and nature conservation activities.

Further development of this mechanism with different degree of completeness was carried out in the land, water, forest, legislation on the subsoil, on the protection of atmospheric air, resolutions of the Cabinet of Ministers of Ukraine, and in a number of other guidance and regulatory documents developed in accordance with the specified Law.

The emergence of new economic, social and environmental priorities, based on new balanced structures of production and consumption, new technologies and forms of investment, necessitates the transformation of national management systems at local, regional, national and global levels, whose main task is to harmonize relations in the system "nature is society". In this regard, the development of natural resource management systems and their achievement of such a level of perfection, which would ensure the harmonious development of production and natural resource potential, would allow to reconcile the "goals" of human management with the "goals" of self-regulation of natural ecosystems and avoid environmental degradation. It is scientifically substantiated that the advancement of Ukraine on the trajectory of sustainable development through a balanced consistent structural policy is impossible without defining the ecological dominant as a qualitatively new paradigm of environmental management.

The development of economic theory changed and updated the content of the category "economic development", expanding and supplementing the number of factors that influence the process of economic development of the world. The main factors affecting the process of economic development include the improvement of the level of skills of employees, innovation, NTP (knowledge, science, technology, technology), improvement of the quality of capital resources. However, the key, even stimulating, factor in economic development today is the deterioration of the environment. It is the deterioration of the environment that pushes both people and society towards self-preservation, which is impossible without improving the level of skills of employees, enhancing innovation, improving the quality of capital resources and improving technology.

Economic growth is an integral part of economic development. Economic growth is the quantitative growth of such indicators of the economy as: GDP growth, growth of economically active population, aggregate supply and demand, capital, etc. There are extensive and intensive types of economic growth.

\footnotetext{
${ }^{1}$ Галушкіна, Т. П. (2006). Екологічний менеджмент та аудит рекреаційних територій (концептуальні засади та організаційний механізм). Одеса: ІНВАЦ.

${ }^{2}$ Буркинський, Б. В., Галушкіна, Т. П. (2006). Глобалізація економіки та національна екологічна доктрина. Економіст, 9, 20-23.

3 Данилишин, Б. М., Дорогунцов, С. І., Міщенко, В. С. (1999). Природо ресурсний потенціал сталого розвитку України. Київ: РВПС України НАН України.

${ }^{4}$ Дорогунцов, С. І., Хвесик, М. А., Головинський, І. Л. (2002). Водне господарство Украйни: сучасний стан та перспективи розвитку. Київ: РВПС України НАН України.

${ }^{5}$ Хвесик, М. А., Голян, В. А. (2006). Інституціональне забезпечення землекористування: теорія і практика. Київ: Книжкове вид-во НАУ.

${ }^{6}$ Коломийчук, В., Шевчук, Л., Шульга, С. (2002). Стратегічні засади соиіальної економічного розвитку регіону (на матеріалах Тернопільської області). Львів: Львівська брама.
} 
A characteristic feature of extensive type of growth is an increase in production due to the additional involvement of labor and production potential and an increase in the extraction of natural resources, which eventually results in the degradation and destruction of the environment. It is obvious that the extensive type of economic growth is environmentally harmful and anti-economic, that is, from a certain point in time, the environmental losses of mankind will increase faster than it will produce benefits to meet their needs. In turn, intensive economic growth involves the efficient use of natural resources through a new safe combination of factors of production, which allows us to preserve the environment and to enhance the economic well-being of both the individual and society as a whole.

Intensive type of economic growth is the form in which economic development should manifest itself in the modern economy. In its framework, on the one hand, provided high quantitative indicators, and the second - is the restructuring of the economy. In other words, intensive type of economic growth is a powerful impetus for changing the economy, its transition from one stage of development (pre-industrial, industrial) to another, new, more advanced (post-industrial).

Economic development at the pre-industrial, industrial and post-industrial stage can occur both extensively and intensively. Extensive type of economic growth is accompanied by quantitative shifts in the economy with its constant structure. Due to the extensive type of economic growth, the creation of GDP per capita is due to the functioning of environmentally dangerous industries.

The intense type of economic growth is accompanied by qualitative shifts in the economy and changes in proportions in its structure. Due to the intense type of economic growth, the level of anthropogenic load on the environment is reduced due to the increase in the production of high-tech, science-intensive and environmentally friendly products, which has a positive impact on the state of the natural environment around the world. At the postindustrial stage of development, the intense type of economic growth breaks down into sustainable and environmentally polluting subtypes of development. The nature-polluting subtype of development leads to an increase in the well-being of each member of society and an increase in anthropogenic load on the environment. Sustainable development subtype contributes to the welfare of every member of society. But unlike the nature-polluting subtype of development, there is a reduction in the level of man-made load on the environment. That is, the "sustainable subtype of development" is economic development in the conditions of formation of post-industrial society, which is accompanied by structural shifts that contribute to the simultaneous reduction of man-made load on the environment and increase of well-being.

The most important functional elements of the state environmental management system are the following components of the economic mechanism of environmental management and environmental activities, namely:

- mechanisms for collecting environmental pollution and for the special use of natural resources;

- the mechanism of compensation for damages caused by violation of environmental legislation.

The economic mechanisms of environmental management and conservation in Ukraine are based on the following main principles:

- payment for the special use of natural resources and for the harmful impact on the environment;

- the targeted use of funds from fees for special use of natural resources and environmental pollution to eliminate sources of pollution, restore and maintain natural resources in a proper state.

The main purpose of the economic mechanisms of environmental management and conservation is:

- stimulation through the introduction of environmental and economic instruments of environmental users to reduce the adverse impact on the environment, rational and economical use of natural resources and reduce the energy and resource intensity of the unit of production;

- creating a source of funding for environmental measures and works at the expense of funds received from environmental fees and payments, independent of state and local budgets.

With the adoption of the new version of the Law of Ukraine "On Environmental Protection" , the legislative, institutional and regulatory frameworks are being restructured. At present, one of the priority areas for the implementation of environmental policy is the improvement of the system of integrated environmental management, interagency coordination, mandatory integration of the environmental component into the programs of development of economic sectors. To this end, a number of measures have been implemented in Ukraine and regulatory documents have been adopted, the adoption of which in the

\footnotetext{
1 Закон про охорону навколишнього природного середовищза, 1991 (Верховна Рада України). Офіиійний сайт Верховної Ради Украӥни <https://zakon.rada.gov.ua/laws/show/1264-12> (2020, June, 20).
} 
future will create conditions for improving the effectiveness of environmental policy by improving legislation and bringing it in line with international standards and requirements ${ }^{1}$.

In this regard, the idea of developing appropriate initiatives towards the implementation of an effective model of environmental resource management is declared, taking into account certain limitations that exist in the territorial context ${ }^{2}$. These include, but are not limited to:

- legally declared status of the territory (such as recreational, nature protected, etc.);

- the originality and uniqueness of the nature of the resource potential;

- limited property rights;

- level of development of environmental infrastructure;

- the effectiveness of environmental management tools at the local level;

- level of environmental awareness and mentality of the local community.

Thus, the prerequisites for the development of environmental management can be considered:

- threatening state of use and deepening degradation of natural resources;

- the ineffectiveness of the judicial system regarding the protection against overexploitation of the nature of the resource potential, including at the regional level;

- insufficient development of the legislative and regulatory framework on the regulation of rational environmental management at the state level;

- lack of appropriate state institutions that ensure the development of innovations and the transfer of green technologies;

- insufficient role of public institutes and environmental education.

In view of the above, it can be argued that the ideological platform of resource management needs to be more clearly defined in the spatial context. Resource management is a qualitatively new model of environmental management in the spatial context, which aims at ensuring the rational use and conservation of natural resource potential on the criteria of sustainable development, resource conservation and dominance of national interests.

It can be stated that, traditionally, the assessment of the efficiency of the use of the natural resource potential is determined mainly by the level of increase of the volumes of environmental fees / payments and their revenues to the budgets of all levels. However, according to the research, the volumes of accumulated financial resources from fees for special use of natural resources in the Consolidated Budget, showing the increase of absolute values, show, first, the reduction of their share in the total amount of the Consolidated Budget by years, and secondly a constant imbalance between the revenue and expenditure components. Over the last decade, significant fluctuations in resource efficiency have been observed, which are proposed to be calculated as the ratio of the amount of expenditures for the protection and rational use of natural resources to the fee for special use of natural resources, especially at the local level.

It should be noted that in Ukraine for many years the inappropriate use of funds received from fees for the special use of natural resources, in particular, water resources, discredit the main purpose of making these fees and negate the effects of the main levers of the economic mechanism of environmental management, aimed in particular at protection and reproduction water resources.

Significant fluctuations in the efficiency ratio of resource use, especially at the local level, indicate an underfunding of the environmental sector, since natural resource receipts under the environmental legislation must have a targeted nature of use.

Together with the reduction of the share of fees for special use of natural resources in the revenues of the consolidated budget of Ukraine, over the last decade, the tendency to widen the gap between the amount of revenues from the fees for special use of natural resources to the State and local budgets and expenditures for their protection has prevailed.

The existing environmental management system is based on the performance of distributive functions by its subjects and consists of subordinate subsystems, each of which at the level of individual entities has its structural, organizational, scientific, methodological and technical bases. Meanwhile, the operation of the resource management system should be carried out at three levels, distributed according to the territorial principle:

- nationwide - covers the priority areas and objectives of resource management across the country;

\footnotetext{
${ }^{1}$ Галушкіна, Т. П. (2010). Екологічний аудит водогосподарських систем. Одеса: Фєнікс.

2 Жемба, А. Й., Галушкіна, Т. П., Пастушенко, О. В. (2008). Теоретичні підвалини формування системи екологічного менеджменту в територіальному розрізі. Вісник національного університету водного господарства та природокористування, 4 (44), 24-34.
} 
- regional - covers priority directions and tasks of resource management on a territorial scale;

- local - covers priority directions and tasks of resource management on the scale of individual territories (sites) with high anthropogenic load.

It is necessary to define strategic vectors for improving the legislative and regulatory field in the direction of ensuring the principles of resource management. In this context, it is proposed to supplement the existing legislative framework with qualitatively new postulates in the context of establishing effective resource management and to consider the feasibility of more prudent planning in this area, which, first, should eliminate the existing imbalance between budgetary resources and their expenditures for environmental protection, secondly, to set a lower regulatory limit for these indicators within the state (local) budgets;

Conclusion. The rational use and reproduction of natural resources have become one of the most pressing problems of humanity. Along with the global, the problem of environmental protection and the rational use of natural resources has a pronounced regional character and plays a special role in the intensification of production based on the acceleration of scientific and technological progress.

In addition, it is advisable to better formulate a strategy for environmental management of the region, taking advantage of the potential for renting budgets at all levels. Strengthening the financial component of environmental management at the regional level is an essential part of implementing a plan of action to ensure a proper return on natural capital.

Thus, the development of environmental management is determined by the possibilities of resolving issues, on the one hand, on the state and volume of financing in the field of environmental protection, use of natural resources and guaranteeing environmental safety, and on the other, on the effectiveness of functioning of the mechanism of financing environmental measures. Therefore, the formation of a more efficient system of economic regulation and financing of environmental activities, a strong financial basis for the conservation of natural resources, especially at local and regional levels.

\section{References:}

1. Strategiya nacionalnoyi ekologichnoyi politiki na 2010-2020 roki (Kabinet Ministriv Ukrayiny). [National Environmental Policy Strategy for 2010-2020 (Cabinet of Ministers of Ukraine)]. Oficijnyj visnyk Ukrayiny [Official Bulletin of Ukraine] <http:// ueplac.kiev.ua/downloads/outputs/output_00331.pdf> (2020, June, 20). [in Ukrainian].

2. Cili rozvytku tysyacholittya - Ukrayina (Minysterstvo ekonomiky Ukrayiny). [Millennium Development Goals Ukraine (Ministry of Economy of Ukraine)] <http://un.org.ua/images/SDGs_NationalReportUA_Web_1.pdf> (2020, June, 20). [in Ukrainian].

3. Rozporyadzhennya pro zatverdzhennya Natsional'noho planu diy z okhorony navkolyshn'oho pryrodnoho seredovyshcha na 2011-2015 roky, 2011 (Kabinet ministriv Ukrayiny) [Order approving the National Action Plan for Environmental Protection for 2011-2015, 2011 (Cabinet of Ministers of Ukraine)]. Ofitsiynyy sayt Verkhovnoyi Rady Ukrayiny [Official site of the Verkhovna Rada of Ukraine] <https://zakon.rada.gov.ua/laws/show/577-2011$\%$ D1\%80> (2020, June, 20). [in Ukrainian].

4. Galushkina, T. P. (2006). Ekologichnij menedzhment ta audit rekreacijnih teritorij (konceptualni zasadi ta organizacijnij mehanizm). [Environmental management and audit of recreational areas (conceptual framework and organizational mechanism)]. Odesa: INVAC. [in Ukrainian].

5. Burkinskij, B. V., Galushkina, T. P. (2006). Globalizaciya ekonomiki ta nacionalna ekologichna doktrina [Globalization of the economy and national environmental doctrine]. Ekonomist [Economist], 9, 20-23. [in Ukrainian].

6. Danilishin, B. M., Doroguncov, S. I., Mishenko, V. S. (1999). Prirodo resursnij potencial stalogo rozvitku Ukrayini [Natural resource potential of sustainable development of Ukraine]. Kyiv: RVPS Ukrayini NAN Ukrayini. [in Ukrainian].

7. Doroguncov, S. I., Hvesik, M. A., Golovinskij, I. L. (2002). Vodne gospodarstvo Ukrayini: suchasnij stan ta perspektivi rozvitku. [Water management of Ukraine: current state and prospects for development]. Kyiv: RVPS Ukrayini NAN Ukrayini. [in Ukrainian].

8. Hvesik, M. A., Golyan, V. A. (2006). Institucionalne zabezpechennya zemlekoristuvannya: teoriya i praktika. [Land use institutional assurance: theory and practice]. Kyiv: Knizhkove vid-vo NAU. [in Ukrainian].

9. Kolomijchuk, V., Shevchuk, L., Shulga, S. (2002). Strategichni zasadi socialnoyi ekonomichnogo rozvitku regionu (na materialah Ternopilskoyi oblasti) [Strategic foundations of social economic development of the region (based on Ternopil region materials)]. Lviv: Lvivska brama. [in Ukrainian].

10. Zakon pro ohoronu navkolishnogo prirodnogo seredovisha, 1991 (Verkhovna Rada Ukrajiny). [Law of Environmental Protection, 1991 (Verkhovna Rada of Ukraine)] Ofitsiynyy sayt Verkhovnoyi Rady Ukrayiny [Official site of the Verkhovna Rada of Ukraine] <https://zakon.rada.gov.ua/laws/show/1264-12> (2020, June, 20). [in Ukrainian]. 
11. Galushkina, T. P. (2010). Ekologichnij audit vodogospodarskih sistem. [Environmental audit of water management systems]. Odesa: Fyeniks. [in Ukrainian].

12. Zhemba, A. J., Galushkina T. P., Pastushenko, O. V. (2008). Teoretichni pidvalini formuvannya sistemi ekologichnogo menedzhmentu v teritorialnomu rozrizi [Theoretical bases of formation of ecological management system in territorial section]. Visnik nacionalnogo universitetu vodnogo gospodarstva ta prirodokoristuvannya . [Bulletin of the National University of Water Management and Environmental Management], 4 (44), 24-34. [in Ukrainian]. 